\title{
THE STATUTORY EVOLUTION OF THE EXCESS PROFITS TAX
}

\author{
C. Rudolf Peterson*
}

It is less than three years since Congress, following the example of World War I, enacted a general excess profits tax-the Excess Profits Tax Act of I940. In the intervening period there has been one act, the Excess Profits Tax Amendments of r94I, devoted entirely to amendment of the original provisions; a second, the Revenue Act of I94I, which made further important amendments; and now recently a third, the Revenue Act of 1942, which, of its 208 pages, contains 47 on the subject of excess profits-20 more than the original Act itself. Inter arma non silent leges.

The I940 Act came as a result of the greatly accelerated defense effort which was one of the consequences of the German successes in the West in the spring of that year. On May I6, the President urged upon Congress the pressing necessity for increased defense expenditures. ${ }^{1}$ Congress responded immediately and, to assist in financing the additional appropriations, passed the Revenue Act of I940 (to be distinguished from the Second Revenue Act of I940, Title II of which constituted the Excess Profits Tax Act of I940). By this Act, individual surtax rates were increased, personal exemptions were reduced, corporate rates were raised by $\mathrm{x} \%$, and a defense tax of $10 \%$ of the tax otherwise computed was imposed on all taxpayers, individuals and corporations alike, for a period of five years. This Act was approved June $25^{\text {th. }}$

The administration next turned its attention to the social consequences of the greatly increased expenditures to be made by the Government for war purposes, the major problem being the extent to which taxpayers should be permitted to make money out of the national emergency. Since I934, as an incident to the naval expansion program which began approximately at that time, there had been on the books a statute, the Vinson-Trammell Act, providing for the recapture of excessive profits on certain government contracts. ${ }^{2}$ By 1940 this statute, which had originally been limited to contracts for the construction of naval vessels and naval aircraft, had been enlarged so that it also covered contracts for the construction of army aircraft. This type of legislation, however, was not adequate in the face of the greatly ex-

\footnotetext{
* A.B., 1928, Princeton; LL.B., 193 I, Columbia. Member of the New York and District of Columbia Bars, Washington, D. C.

${ }^{1}$ H. R. Doc. No. 75I, 76th Cong., 3d Sess. (1940).

${ }^{2} \S_{3}$ of the Act of March 27, I934 (48 STAT. 505; 34 U. S. C. $\$ 496$ ), as amiended, and $\S_{2}$ (b) of the Act of June 28, 1940. Sce also $\$ 505(b)$ of the Merchant Marine Act of 1936, as amended.
} 
panded program for national defense upon which the country was embarking under the threat of war. On July $x$, I940, in recognition of this fact, the President addressed a communication ${ }^{3}$ to the Congress which referred to the great national defense effort in which the country was then engaged, to which "even our humblest citizens" were being asked "to contribute their mite," and stated that it was the Government's duty to see that the burden was equitably distributed according to ability to pay so that a few should not gain from the sacrifices of the many. "The enactment of a steeply graduated excess-profits tax, to be applied to all individuals and all corporate organizations without discrimination," was therefore strongly recommended.

The enactment of an excess profits tax was immediately considered by Congress and became part of a three-point program, the other parts of which were provision for the five-year amortization of emergency facilities and suspension of the profitlimiting provisions of the Vinson-Trammell Act. The entire program was first referred for study to a subcommittee of the Committee on Ways and Means, which presented its report on August 8th. In this report the President's recommendation that the excess profits tax apply to individuals and partnerships as well as to corporations was abandoned and the proposed tax was limited to corporations only. This conclusion was reached not only because of the difficulties of devising a tax of this nature which could be applied to noncorporate taxpayers with any accuracy, but also because an additional levy was made unnecessary by the high rates of surtax applicable to individuals, coupled with the fact that there could be no avoidance of such taxes by leaving profits in the business as in the case of a corporation. There has been no serious attempt to alter this basic policy, though a number of trial balloons have recently been raised to test public reaction to a proposal to incorporate a noncorporate excess profits tax in a possible I943 bill.

With the general issue of the scope of the tax out of the way, the subcommittee proceeded to make specific recommendations as to the precise form the tax was to take. Discussion of the details of the Act which evolved and subsequent developments will center on a few broad categories, as follows: (a) determination of excess profits, (b) rate structure, (c) relationship between the excess profits tax and the income tax, (d) computation of excess profits net income, (e) so-called relief, and (f) treatment of special types of corporations.

\section{Excess Profits}

\section{(a) General}

The major consideration in any excess profits tax system is the standard by which it is determined how much of a taxpayer's profits are excess profits.

Under the Vinson-Trammell Act, ${ }^{4}$ with its limited scope, the measure of profits permitted to be retained was a stated percentage of the contract price. Everything in excess of such stated percentage was required to be refunded to the Government. The same method was employed in the case of contracts or subcontracts subject to

\footnotetext{
${ }^{8}$ H. R. REP. No. 2894, 76th Cong., 3 d Sess. (1940) 2. 'See note 2, supra.
} 
the provisions of Section 505(b) of the Merchant Marine Act of I936, as amended. Regardless of whether such a method may be justified where the statutory restrictions apply only to certain contracts which may constitute only a part of the taxpayer's business, it was considered obviously inappropriate in a general excess profits tax act.

In determining the proper measure of excess profits, it is first necessary to decide the type of profits which the tax is intended to reach. Is the basic policy to be the regulation of profits in a manner similar to that in which the profits of a public utility are regulated, that is, is the concept to be one of unreasonable profits? Or is it intended only to tax profits to the extent they exceed peacetime profits, that is, is the concept to be one of war profits? The former would measure the excess profits credit by an assumed fair return on the capital invested in the business, the latter by normal earnings. Congress, from the beginning, solved these questions by permitting taxpayers to use whichever method was the more favorable. This has sometimes produced confusion of thought in analyzing particular cases and makes impossible any exposition of the statute along simple and direct lines, but it was thought that a double-headed system would go far toward eliminating hardships and the necessity for the vague and discretionary type of relief which characterized the World War I excess profits tax act. In this respect expectations have unfortunately not been fulfilled, but, on the contrary, a broad and far-reaching relief system has been found to be imperative if inequity is to be avoided.

At the outset, the Treasury urged the invested capital plan as the sole method for determining excess profits and, even though the Treasury was unsuccessful in having its recommendations in this respect adopted, the invested capital credit was clearly the dominant one in the early stages of the Act's development. One of the most conspicuous features of the evolution of the excess profits tax, however, has been the shift in emphasis from the invested capital credit to the average earnings credit, so that now the latter credit is clearly the primary one. The major problems of excess profits tax relief are solved in terms of an average earnings credit, hypothetical or real, and whatever liberalizing changes have been made in the credit system have on the whole been confined to the average earnings as opposed to the invested capital credit. Indeed, at one stage of the Act's development, what was in effect a penalty tax upon the use of the invested capital credit was proposed.

\section{(b) Development of Excess Profits Credits}

\section{(I) Original Proposals}

As has already been indicated, the Treasury originally favored an invested capital plan exclusively. In fact, the invested capital provisions of the House Bill in 1940 may be said to represent the Treasury's concept of an excess profits credit, the average earnings plan, which was also contained in that Bill, having been included in the face of stern resistance by the Treasury. Yet the Treasury's invested capital plan included some measure of base period experience. As such, it represented 
something of a compromise, which will be fully appreciated when it is remembered that it was developed with the idea that it would constitute the sole available credit. When the average earnings credit was added and sufficient time had elapsed for an examination of the relationship between the two credits, it was seen that the need for this element had disappeared.

The Treasury plan was extremely complicated but may be briefly summarized as follows: Excess profits net income for each base period year was determined. Likewise, a computation was made of the taxpayer's invested capital covering the base period. On the basis of these figures the average rate of return for the base period was ascertained and this percentage, called base period percentage, was the basic rate of return to be allowed in computing the excess profits credit to the extent the corporation's invested capital represented a continuation of that employed during the base period. However, a floor of $7 \%$ and a ceiling of $10 \%$ were placed on the first $\$ 500,000$ of invested capital and the same ceiling but a lower floor $(5 \%)$ on the remainder of the corporation's invested capital. To the extent that the corporation's invested capital for the taxable year exceeded the invested capital at the close of the base period, it was considered new capital, entitled to a $10 \%$ return on so much as did not bring the total invested capital above $\$ 500,000$ and $8 \%$ on the remainder. The concept of invested capital also included borrowed capital, but not at a uniform rate of $50 \%$. Varying proportions were included, depending upon the size of the corporation.

The original Bill likewise contained an average earnings credit. It had many limitations, however. In the first place, it was available only to corporations in existence for the entire 48-month period preceding the beginning of the first excess profits tax taxable year. Although $100 \%$ of the average base period net income was allowed to be employed, the use of the credit was penalized by a rate schedule which was five percentage points higher in each bracket than that applicable when the invested capital credit was used, and by the further imposition of what was in effect an increase in the normal tax rate from $20.9 \%$ to $25 \%$.

\section{(2) Development in the Senate}

When the Bill reached the Senate, changes in the invested capital credit were largely in the interest of simplification, made possible in considerable degree by the incorporation of an alternate average earnings credit. All elements of base period experience were eliminated and a flat $8 \%$ rate of return was substituted. The complicated schedule governing the inclusion of borrowed capital was likewise abolished, and, in lieu thereof, a uniform rule for the inclusion of all borrowed capital at $50 \%$ was provided. Thus, the invested capital credit was brought substantially to its present form so far as its general structure was concerned, though later changes (principally with regard to rates) have considerably altered its effect in individual cases. 
The Senate likewise made changes in the average earnings credit. Some of the Senate amendments were yielded in conference, but the average earnings credit as finally enacted was less of a stepchild than it was in the House Bill. A taxpayer employing such credit was not subjected to any higher or different rates of tax than its invested capital counterpart. In return for this concession, however, the amount of average base period net income which could be employed was reduced from $100 \%$ to $95 \%$. The availability of the credit was greatly enlarged. Corporations which were not in existence for the entire 48-month period preceding the beginning of their first excess profits tax taxable year were given the privilege of using the credit, provided they were not organized after December 3I, I939. Vacant years in the base period were given an excess profits net income equal to $8 \%$ of the taxpayer's invested capital as of the day following the close of the base period. A further liberalizing provision, which would have allowed the average to be based upon the best three out of four years in the base period, was lost in conference.

\section{(3) Subsequent Developments}

The most important liberalizing amendment of the average earnings credit which has been adopted since the r940 Act is found in the Excess Profits Tax Amendments of 194I. The original average earnings credit was computed strictly on a general average basis, that is, average base period net income was merely the algebraic sum of the excess profits net incomes for the several base period years, divided by four. The only concession which was made was that a deficit in excess profits net income for one year (or the largest, if there were deficits in more than one year) could be treated as zero. The Excess Profits Tax Amendments of I941 added an alternate method, commonly known as the "growth formula." Under this method, the average base period net income was in effect the average for the last two years of the base period plus one-half the difference between the first half average and the second half average. A number of limitations were appended to the provision to prevent war income from inflating the credit and to make certain that the average base period net income did not exceed the highest excess profits net income for any single year in the base period. But the provision was, nevertheless, a great boon to "corporations whose facilities and production capacities were substantially increased during this [the base] period," the object being to prevent such corporations from being "penalized as compared to corporations which had already achieved and maintained a high and constant level of production."

The beginning of a change in emphasis from the invested capital credit to the average earnings credit is also apparent in the approach which the Excess Profits Tax Amendments of $\mathrm{x} 94 \mathrm{I}$ took to the question of general relief. No attempt was made to provide for curing abnormalities in invested capital, but an elaborate provision was enacted for curing abnormalities in base period net income. The possibility of substituting a constructive average base period net income for an actual

${ }^{5}$ H. R. Rep. No. 146, 77th Cong., Ist Sess. (1941) 3. 
average base period net income which was unrepresentative of the taxpayer's normal earning power obviously increased the number of cases in which the average earnings credit provided by Section $7 \mathrm{r}_{3}$, as opposed to the invested capital credit set forth in Section 7I4, "could be advantageously employed.

The Revenue Act of I94I contained no changes in the average earnings credit, but the policy reasons for retaining such a credit were emphatically reaffirmed in terms which indicate that that credit was already being thought of as the dominant one. Two changes were made in the invested capital credit, however. One reduced the rate of return on invested capital in excess of $\$ 5$ million from 8 to $7 \%$. The other made provision for giving a higher rate of return on capital invested in the business after I 940 by permitting its inclusion in invested capital at $125 \%$ rather than $100 \%$. The net balance was a continuation of the downward curve of the invested capital credit's importance. Of considerable significance in indicating the trend were two other circumstances occurring at this time, one involving a provision which was included in the Bill at one stage, ${ }^{\mathfrak{c}}$ but was later defeated, and the other a collateral change having a bearing on the relative effects of the two types of credits. The first was the proposal for a special $10 \%$ tax on the amount of ad. justed excess profits net income which was saved from excess profits tax by the use of the invested capital credit rather than the average earnings credit. The purpose of this provision was to impose some additional tax upon war profits realized by corporations which had never had a rate of return as high as that allowed by Section 714 and were consequently insulated against a special tax on war profits by that provision. The second was the change in the relationship of the excess profits tax and the income tax, discussed under heading III. By reversing the order of deductions, so that the income tax was no longer deductible in computing the excess profits tax, a greater burden was placed on the use of the invested capital credit. Where the average earnings credit was used, the increase in current excess profits net income was at least partly offset by the elimination of the requirement that base period income be reduced by the amount of the income taxes thereon.

The average earnings credit was further expanded in the Revenue Act of 1942 by the belated inclusion of a provision half way between treating a deficit year as zero and permitting the average to be computed on the basis of three out of four years. In computing average base period net income under the general average method, the taxpayer is now permitted to raise his lowest year to an amount equal to $75 \%$ of the average for the other three years. The r942 Act also greatly expanded the general relief provision, which will be discussed later. Even corporations not previously entitled to use the average earnings plan are now given that privilege, by being embraced within the scope of the relief provision if they can show that invested capital is an inadequate standard for determining excess profits in their

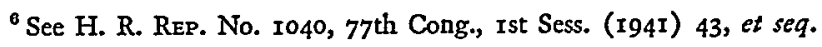


case and can establish a constructive average base period net income which is a fair standard of normal earnings.

At the same time, further reductions were made in the rates of return permissible in the case of the invested capital credit. The original $8 \%$ return now applies only to the first $\$ 5$ million of invested capital, the next $\$ 5$ million being limited to a $7 \%$ return, the next $\$$ rgo million to $6 \%$, and all in excess of $\$ 200$ million to $5 \%$.

Mention has not thus far been made of the method employed by the Act for computing equity invested capital. It is commonly known as the "tax basis" rule. Equity invested capital is not the present stockholders' investment, nor is it the company's net worth at a given date, such as January $x$, I940. It is a historical figure representing the amount of money or property paid in for stock or as paid-in surplus or as a contribution to capital, plus accumulated earnings and profits, less capital distributions. Property paid in is included at its tax basis rather than its then value, which operates as a limitation upon the amount of invested capital in the case of a tax-free reorganization involving assets which have appreciated in value, since in such cases the tax basis ordinarily reflects only cost to some preceding owner and not taxpayer's cost. This rule can also operate to produce an invested capital much. higher than taxpayer's cost, in cases involving the reorganization of companies in whose asset account is included a large amount of unrealized depreciation. The merits or demerits of the tax basis rule will not be discussed here, except to say that its advocates argue that to urge a cost rule is in effect to insist upon the reflection of earning power, which should already be adequately reflected in the average earnings credit. They point out that the invested capital credit is intended to represent an entirely different theory, that of original investment, and that it is really a relief credit, available when the credit based on earning power proves unsatisfactory. Its opponents present the simple argument that it is ridiculous to say that, when $\$ 1,000,000$ worth of property is paid in for a corporation's stock, its invested capital is only $\$ 100,000$, because the corporation must take the property over for income tax purposes at the lower figure as a consequence of non-recognition of gain to the transferor.

\section{(4) Summary of Credit Structure Currently in Effect}

The Excess Profits Tax Act provides for two credits in determining adjusted excess profits net income, the invested capital credit and the average earnings credit. ${ }^{7}$ Of these, the average earnings credit is now clearly the dominant credit; the invested capital credit being largely a relief credit. The structure of these credits may be briefly summarized as follows:

\footnotetext{
"Originally the taxpayer was required to make an irrevocable election on its return as to which credit was to be employed for the taxable year. Almost immediately, however, the election feature was abandoned, and the question of the applicable credit was made to turn on which resulted in the smaller tax, unless one or the other credit was specifically disclaimed on the return. Even the disclaimer provision has now been eliminated, and only the relatively simple rule remains that the applicable credit is that which produces the smaller tax.
} 


\section{A. Invested Capital Credit}

The invested capital credit is $8 \%$ of the first $\$ 5$ million of invested capital, $7 \%$ of the next $\$ 5$ million, $6 \%$ of the next $\$ 190$ million, and $5 \%$ of all over $\$ 200$ million. Invested capital consists of money or property paid in for stock, as paid-in surplus, or as contribution to capital, plus accumulated earnings and profits, plus $50 \%$ of borrowed capital, less corporate distributions previously made to shareholders. This, however, does not represent present investment, but historical investment, because of the use of the tax basis rule. On the other hand, the only reductions of original capital which are taken into account are those resulting from distributions. Accumulated operating deficits are ignored. In addition to the basic sections, $7 \mathrm{I}_{4}$ through 720 , dealing with the invested capital credit, an entire Supplement is devoted to the special problems arising out of corporate reorganizations and liquidations. In the case of reorganizations, the general effect is to carry over the predecessor's invested capital as nearly as may be, unless there is a shift from equity to borrowed capital or a capitalization of unrealized appreciation in the form of debt, in which case the indebtedness is treated as a distribution. The effect of this refinement is sometimes to produce a minus invested capital, as in the case where the $X$ Corporation, with $\$ 100,000$ of invested capital (all equity) but assets which have appreciated to $\$ 1,000,000$, reorganizes into the $Y$ Corporation, with $\$ 100,000$ of stock and $\$ 900,000$ of bonds, all the bonds representing capitalization of unrealized appreciation. The bonds will be treated as a distribution, producing equity invested capital of minus $\$ 800,000$. Borrowed invested capital being only $\$ 450,000$, the total invested capital is still a minus figure to the extent of $\$ 350,000$. Another result of a reorganization is that the benefits of the deficit rule may be lost, except in a very narrow class of identity reorganizations the requirements of which will seldom be met. In the case of tax-free intercorporate liquidations, the general effect of Section $76 x$ is to preserve the parent's invested capital where the subsidiary's stock was held at a cost basis, but to eliminate the underlying invested capital of the parent and substitute therefor that of the subsidiary where the stock was held with a substituted or carryover basis. Detailed discussion of these provisions will be found elsewhere in this issue.

\section{B. Average Earnings Credit}

This credit was never really fully developed at the start, and its development subsequently has come largely through the refinements to be found in the relief sections. The basic average earnings credit consists of $95 \%$ of the taxpayer's average base period net income, plus $8 \%$ of any net increase, or minus $6 \%$ of any net decrease, in paid-in capital after the close of the base period. Average base period net income is either the arithmetical average of the taxpayer's experience for the base period, or an amount equivalent to the average for the second half of the base period, plus one-half the excess of such average over that for the first half. If the general average method is used, the taxpayer may substitute as the income for its 
poorest year $75 \%$ of the average for the other three, but if the growth method is employed, actual experience must be used for all years (except for experience after May 3I, I940, in the case of fiscal year taxpayers, which need not be discussed here). Like the basic invested capital provisions, the basic average earnings credit provisions are accompanied by a Supplement-Supplement $A$-covering certain types of reorganization. The function of this Supplement is to provide for a carry-over of base period experience from a predecessor to a successor corporation.

\section{RATES}

All the excess profits tax rate schedules until the present one have involved several brackets with graduated percentages. In the original subcommittee report, the following rate schedule was recommended:

$25 \%$ of so much of the adjusted excess profits net income as does not exceed $10 \%$ of the excess profits credit;

$30 \%$ of so much of the adjusted excess profits net income as exceeds $10 \%$ of the excess profits credit and does not exceed $20 \%$ of such credit;

$40 \%$ of so much of the adjusted excess profits net income as exceeds $20 \%$ of the excess profits credit.

Obviously, under such a rate schedule the dollar amount includible in each bracket would vary from taxpayer to taxpayer. But it was precisely this which recommended it. The brackets being based upon degrees of excessiveness, there was no discrimination between the large and the small corporation.

This proposed treatment did not long survive consideration by the full committee, however. In the Bill as reported to the House the principle of graduated rates was preserved, but the brackets were measured by dollar amounts of adjusted excess profits net income and there were six brackets instead of three. Furthermore, there was a difference between the schedule applicable when the invested capital credit was used and that applicable when the average earnings credit was used. In the former case the schedule began with a tax of $20 \%$ on the first $\$ 20,000$ of adjusted excess profits net income and increased by 5 percentage points in each bracket until the maximum rate of $45 \%$ on so much of the adjusted excess profits net income as exceeded \$500,000 was reached. In the latter case, though the dollar amounts of the brackets were the same, the percentage range was from 25 to 50 . In addition, taxpayer using the average earnings credit was required to pay a tax of $4.1 \%$ of its normal tax net income. The penalty which this system imposed on the use of the average earnings credit is obvious. It also noticeably favored small corporations as against large corporations by virtue of having fixed brackets measured by dollar amounts of adjusted excess profits net income.

In the Senate the discrimination against the use of the average earnings credit was violently attacked and, in the Bill as reported by the Finance Committee, it was eliminated. In lieu of the dual rate schedule in the House Bill and the additional penalty tax of $4.1 \%$ of normal tax net income, the reported bill contained 
only one rate schedule, applicable to all taxpayers, being that with a percentage range from 25 to $50^{8}$ A floor amendment attempted also to eliminate the discrimination against large corporations which resulted from the method of measuring the brackets. This was done by expanding the provision already in the bill so as to make the determination of each bracket depend upon either a dollar amount of excess profits net income or a percentage of the excess profits credit, whichever of the specified amounts was larger. There was a lack of coördination between the dollar amounts and the percentages in each bracket, however. Consequently, a taxpayer whose income covered several brackets might find the applicability of one bracket controlled by one of the alternate rules and the applicability of another bracket by the other rule, with odd results. This provision did not survive in conference and the rate schedule which ultimately appeared in the Second Revenue Act of r $94^{\circ}$ was the same as that contained in the reported Senate Bill.

One of the consequences of a shift in the House Bill to a rate schedule with brackets fixed on the basis of dollar amounts of adjusted excess profits net income was the creation of the concept of highest bracket amount. Obviously, under the rate schedules as proposed, considerable advantage would result from the reorganization of a large enterprise into a series of separate corporations, since by having the income accrue to a series of corporations in the lower brackets the comparatively high rates into which the bulk of the income would otherwise fall could be avoided. A complicated device was therefore invented for reducing the income taxable at the lower rates in the case of corporations formed under these circumstances, the object being to collect approximately the same tax from the group of corporations collectively as would have been payable if the enterprise had not split up. Fortunately, the 1942 rate changes, noted below, made this provision no longer necessary. It was therefore repealed and, in view of the unsatisfactory nature of the provision from the beginning, the repeal was made retroactive to the original Act.

The only rate change made by the Revenue Act of r94I was to increase the rates in each bracket by Io percentage points, but with the Revenue Act of 1942 the scheme of graduated rates was abandoned and a that rate of $90 \%$ was substituted. This high rate is somewhat tempered by a ceiling provision, limiting the excess profits tax to an amount which, when added to the normal tax and surtax, will produce a combined tax not in excess of $80 \%$ of the corporation's surtax net income. A postwar credit is also provided, amounting to $10 \%$ of the corporation's excess profits tax. This credit may be availed of either by the acceptance of non-interestbearing bonds which are non-negotiable and non-transferrable until the end of the war or through a credit for debt retirement in the taxable year. Both the $80 \%$ ceiling and the postwar credit were declared in the Finance Committee Report ${ }^{0}$ to be for the purpose of cushioning the impact of the severe $90 \%$ rate in certain unusual cases and of providing incentive for economical management and funds for

\footnotetext{
${ }^{8}$ At the same time the normal tax rate was increased from $20.9 \%$ to $24 \%$.

${ }^{\circ}$ SEN. Rep. No. I63I, 77th Cong., 2d Sess. (1942) 29.
} 
postwar rehabilitation in the case of all corporations subject to the excess profits tax. The only remaining concession to small corporations is the specific exemption, whereby the first $\$ 5,000$ of income in excess of the excess profits credit is exempt from excess profits tax. Two attempts, one by the House and one by the Senate, have been made to raise this amount to $\$ 10,000$, but without success.

\section{Relationship Between the Excess Profits Tax and the Income Tax}

One of the most vexing and controversial problems which has arisen in connection with the excess profits tax has been its relationship to the income tax. The fundamental question is whether the determination of excess profits is to be before or after the regular corporate income tax.

The answer which was given in the original Act was to compute the excess profits tax after taxes. This was accomplished by allowing the Chapter I tax to be taken as an additional deduction upon the conversion of normal tax net income into excess profits net income. In the case of the average earnings credit, of course, a similar deduction was required to be taken in determining base period net income.

But this system did not long survive. It was reversed by the Revenue Act of I941, which, in lieu of allowing a deduction of the income tax in computing the excess profits tax, allowed the excess profits tax to be deducted in computing the normal and surtax.

This change has been productive of much criticism. Accusations have been made that it was instituted for no other reason than to increase the revenue. It has been argued that the Chapter I tax liability of a corporation is as much a fixed charge as any other item of operating expense and that true excess profits cannot be determined without taking it into account. On the other hand, there were a number of seemingly valid objections to the original provision. Under it, in effect, a corporation was permitted to use its excess profits to pay Chapter $I$ taxes. If profits increased sufficiently, therefore, a corporation would be allowed to retain a larger proportion of normal profits than had been permitted before, despite an increase in tax rates to which all taxpayers were supposedly subject. This, as has been pointed out, amounted to a discrimination in favor of corporations with increased earnings as a result of the war as against other taxpayers not so situated, since, by in effect subjecting the normal earnings of such corporations to a smaller tax than before the war, it left the increased tax burden to be borne by corporations not fortunate enough to have increased income. It cannot be denied that there was something to be said for the position that the normal earnings of all taxpayers ought to be subject to the same relative tax burden and that excess profits should be treated independently, unaffected by any considerations of the normal tax.

Complete separation of the excess profits tax base and the normal and surtax base was not achieved by the 194I Amendment. For, since only the excess profits tax was allowed as a deduction in computing the income subject to normal and surtax, the differential between the excess profits tax and the adjusted excess 
profits net income was actually used as a tax base twice. With a maximum excess profits tax rate of $60 \%$, this result could perhaps be justified, since it was apparently not the legislative intent to allow excess profits to be retained tax free to the extent of $40 \%$. With the adoption in 1942 of a $90 \%$ rate, clearly a somewhat different situation was presented, calling for further consideration of this controversial subject. The solution adopted was to eliminate any tax deduction either way, but in effect to divide a corporation's income into two categories, normal tax net income and adjusted excess profits net income, subjecting each only to its own tax. It is believed that the correct solution has finally been reached and that the present provision is immune to attack.

If will be noted that the change from the ra40 to the subsequent policy had a more severe effect in the case of the invested capital credit than in the case of the average earnings credit. This was because the disallowance of the normal tax as a deduction increased the excess profits net income for the taxable year without making any corresponding change in the credit. On the other hand, while the current excess profits net income under the average earnings credit was likewise increased, there was also an increase in the credit, less in amount, it is true, but substantial nonetheless, arising from the fact that the income taxes on base period income were no longer deductible in computing average base period net income. As a result, many taxpayers who had found the invested capital credit more beneficial in 1940 found the average earnings credit preferable for $\mathrm{I} 94 \mathrm{I}$ and subsequent years.

\section{Computation of Excess Profits Net Incone}

The income against which the excess profits credit and the specific exemption are allowed and the remainder of which is subject to the excess profits tax is not the net income or the normal tax net income, but the excess profits net income. As in the case of most, if not all, the special types of net income found in various parts of the Internal Revenue Code, however, it is not computed de novo, but is a derivative of an already ascertained figure. Excess profits net income is a conversion of normal tax net income through adjustment of certain items of income, deductions, and credits.

In a loose sense it may be said there are two branches to the question, what are excess profits? The first is, how much? The second is, what kind? The answer to the question of how much is the excess profits credits, which have already been discussed. The answer to the question of what kind is found in the adjustments applied in the conversion of normal tax net income to excess profits net income. Some of these are mechanical, while others involve questions of essential policy. Broadly speaking, there are three categories under which these adjustments may be discussed: (I) Adjustments related to the excess profits credit, (2) elimination of non-recurrent items, (3) relief. The last category will, however, be reserved until the section on relief generally. 
(a) Adjustments Related to the Credit

The adjustments in this category are largely self-explanatory and have been the subject of little controversy.

It will be recalled that borrowed capital constitutes an element of invested capital to the extent of $50 \%$. Since the excess profits credit based on invested capital will include an allowance of from 8 to $5 \%$ on half the corporation's borrowed capital, to allow the interest on the entire borrowed capital to be deducted would obviously result in duplication. From the first, therefore, half the taxpayer's interest deduction which is related to borrowed capital has been eliminated if the invested capital credit is employed.

Another invested capital concept which is reflected in the income computation is the concept of inadmissible assets. The credit feature in this instance, however, is rather the effect than the cause of the corresponding income adjustment. Inadmissible assets consist of stock, wholly tax-exempt federal, state, and local government bonds, and partly tax-exempt federal bonds. To the extent that corporate funds are invested in this type of asset invested capital is reduced. The measure of reduction is the ratio of such assets to total assets.

The corresponding income adjustment consists of the exclusion of income from these sources. In the case of corporate stock, the dividends received credit is increased from $85 \%$ to roo\% and is broadened to include foreign as well as domestic dividends. In the case of wholly tax-exempt federal, state, and local government bonds and partially tax-exempt federal bonds, the same result is achieved without the necessity of specifying an adjustment, since interest from these sources is already excluded from gross income under Section 22(b) (4) or allowed as a credit under Sections $I_{3}(a)(r)$ and $26(a)$. The low rate of return often prevailing on this type of security, however, was thought to make it unfair to require taxpayers in all cases to follow the system of excluding such income and suffering the credit adjustment which the treatment of the bonds as inadmissible assets involved. An option has therefore been conferred upon taxpayers to waive the privilege of tax exemption on such securities for excess profits tax purposes, with the result that the interest received is included in excess profits net income, but in return the taxpayer is not obliged to treat the bonds as inadmissible assets. The effect is to benefit taxpayers, particularly banks and other financial institutions, to the extent that the increase in credit exceeds the income which is thus made subject to tax. In determining whether to avail itself of the option, however, a taxpayer cannot merely compare the invested capital percentages with the interest rate on the bonds, since the inadmissible asset adjustment, being based on a ratio rather than a direct subtraction, will ordinarily fail to correspond with the face amount of the bonds.

It has no doubt been observed that the income adjustments which have been discussed above are all related to the invested capital credit. In the case of the average earnings credit, the problem is merely one of correspondence between the base period and the taxable year computations. 


\section{(b) Elimination of Non-recurrent Items}

The type of adjustment falling under this heading was declared in the original House Report to be "the adjustment of income to take care of ** unusual and non-recurring items" in the interests of "equity and the removal of hardships which would otherwise occur."10 More directly than the adjustments discussed under the preceding heading, these adjustments involve the fundamental problem of determining the kind of income which ought to form the basis for computing an excess profits tax.

The first and most important of these adjustments is that requiring the elimination of long-term capital gains and losses in the computation of excess profits net income. This adjustment has existed from the beginning. A discussion of the pros and cons of this treatment is not within the scope of this article, but it may be pointed out that, though capital gains may in some cases represent income attributable to the war, the isolated nature of capital transactions, the varying periods over which the gain may have accrued both before and after 1940, the fact that a taxpayer may merely refuse to realize a gain if the tax rates are too high, and other factors peculiar to this type of income militate against subjecting it to an excess profits tax. The exclusion of corresponding losses is, of course, merely the normal corollary to the exclusion of gains.

Little change has been made in this adjustment since the original subcommittee proposal in I940. It should be observed, however, that that recommendation assimilated depreciable property with capital assets, with the result that gains and losses from the sale or exchange of depreciable property held over 18 months were likewise eliminated. The Senate modified this treatment to the extent of providing for exclusion only in the case of net gains resulting from this source. A net loss on sales or exchanges of depreciable property held over 18 months was allowed in full.

Of course, the reduction in holding period from 18 months to 6 months in the amendments made to Section IIY by the 1942 Act had the effect of indirectly modifying the adjustment here under discussion. Furthermore, the elimination of a full deduction of capital losses for income tax purposes permitted deletion of any reference to capital losses in the Excess Profits Tax Act. Likewise, the enactment of Section $\operatorname{II} 7(j)$ made a specific reference to depreciable property no longer necessary, since that provision has the effect of making a net gain a capital gain, excludible under the provision dealing with long-term capital gains, while providing that a net loss is to be treated as an ordinary loss, free of the restrictions in respect of capital losses. But these changes are merely technical and do not bear upon excess profits tax policy.

An additional income adjustment incorporated in the original Bill, and one so close to the capital gain adjustment as to be considered almost an expansion of it, was the exclusion of any income derived from the retirement or discharge by a

${ }^{10}$ H. R. REP. No. 2894,76 th Cong., 3d Sess. (1940) 8. 
corporation of its bonds if such bonds had been outstanding for more than I8 months prior to the retirement or discharge. Obviously such an item of income would be non-recurring and, being a peculiar type of income in the first place, scarcely of the kind that should be subjected to an excess profits tax.

As the Bill progressed through the various stages of its enactment a number of other adjustments were added. No particular significance attaches to them, however, since they represented no change in policy, but merely a perfection of the Bill. Thus, the Senate excluded income arising from refunds of processing tax, since this represented in effect merely a compensating adjustment for a deduction taken in I935 or a prior year. Similarly, bad debt recoveries attributable to indebtedness which had been charged off prior to I940 were also excluded, since here too the income was merely to offset a prior deduction, was not a current business item, and could easily be classed as "an unusual and non-recurring" item.

Reference has already been made to the elimination of intercompany dividends in the case of the invested capital credit. A similar elimination is made in the case of the average earnings credit, though foreign dividends are not included. This divergence is difficult to explain in principle and is only partly alleviated by the opportunity to treat foreign dividends as potentially abnormal income under Section 72I. The divergence was even wider in the original subcommittee report and Ways and Means Committee Bill. If the average earnings credit was used, no additional dividends received credit of any sort was allowed. When the Bill reached the Senate the same treatment was provided as in the case of the invested capital credit, but this amendment was compromised in conference by excluding foreign dividends from its scope. It was in connection with this compromise that the foreign dividends category was added to the classes of potentially abnormal income recited in Section $72 \mathrm{I}$.

The discussion under this heading has dealt with adjustments in the conversion of normal tax net income into excess profits net income for an excess profits tax taxable year. It is also necessary, where the average earnings credit is used, to determine excess profits net income for each of the years 1936, 1937, 1938, and 1939. This is done in the main by making the same type of adjustments as are made in the taxable year, the starting figure being normal-tax net income or its equivalent under the Revenue Act in effect for the period in question. But the following additional adjustments require to be noted:

(I) In addition to the adjustment on account of income resulting from bond retirements, there is a similar elimination of deductions for losses, expenses, etc., resulting from the same type of transaction. Through an oversight, the change from an I8 to a 6 month holding period in the case of capital gains and losses under the 1942 Act was overlooked in this instance and no corresponding change has been made in the bond retirement provision.

(2) Casualty, demolition, and similar losses are disallowed. 
(3) Deductions for repayment of processing tax to vendees are disallowed under limitations.

(4) Various deductions, abnormal in kind or in amount, are disallowed.

In addition, for purposes of attaining uniformity in the base period and taxable year computations, the current capital gain and loss provisions are to be applied, including the provisions dealing with carry-overs.

\section{RELIEF}

It is on the subject of relief that the excess profits tax has undergone its greatest development since the original Act of r940. The term "relief," however, is probably a misnomer. The provisions in question are more properly to be called refinements of either the income or the credit computations. They are not acts of grace operating in defiance of the excess profits concept, but perfecting amendments in furtherance of basic policy.

The subcommittee report of August 8, I940, contained a separate section on the subject of special relief provisions, stating that the need for special assessment under the proposed plan was much less than during the World War period. Seven reasons were listed in support of this statement. Briefly summarized they are as follows: the inclusion of an average earnings credit, the inclusion of borrowed capital in invested capital, the inclusion in invested capital of the tangible property paid in for stock without any percentage limitation, the exclusion from excess profits net income of long-term capital gains and losses, the fixing of a floor upon the rate of return allowed for invested capital purposes, the allowance of special rates on new capital, the filling in of vacant years in the base period for invested capital purposes at a $10 \%$ and $8 \%$ return based on invested capital as of the close of the base period. The subcommittee therefore recommended no special relief provisions except in cases where the Commissioner could not determine the taxpayer's equity invested capital at the beginning of the first excess profits tax taxable year. This recommendation is now embodied in Section 723 of the Code, and is commonly referred to as the lost books provision. It is scarcely a relief provision, however, in the generally accepted sense, but merely provides a rule for the computation of equity invested capital in cases where the absence of the necessary information prevents computation under the general rules of Section 718 .

The full Ways and Means Committee professed to have made somewhat more elaborate provision for special relief than its subcommittee had done. But upon analysis the full Committee is discovered merely to have adopted a slightly different definition of special relief from that adopted by the subcommittee. Among the provisions claimed to have been included was that relative to the elimination of long-term capital gains and losses in the computation of excess profits net income, a provision also recommended by the subcommittee but considered by it not as an example of special relief but as a mitigating circumstance which made special relief unnecessary. The other provisions denominated special relief provisions which were 
included in the reported House Bill were the adjustment for repayment of processing tax to vendees, the adjustment for casualty losses, the adjustment excluding income from the retirement or discharge of bonds, and the provision allowing paid-in capital to be unaffected by operating deficits. Some of these adjustments were to base period net income and, by increasing the amount of such income, operated to increase the credit.

The Senate added several further adjustments of the same general nature, and more were added by the Excess Profits Tax Amendments of I94x, some of which in a limited way tended to cure base period abnormalities. The Senate also added Section 72I, dealing with abnormalities in the taxable year-which will be discussed below. The really important provision on the subject of relief, however, was the provision added on the floor of the Senate granting the Commissioner the authority to make any adjustments which abnormally affect income or capital and making his decision subject to review by the Board of Tax Appeals (now The Tax Court of the United States). This provision was completely devoid of standards and was so vague and general that it was never considered as a definitive enactment. It was included merely to have something in the Act on the subject of general relief which would operate as an inducement to the Treasury and members of the Joint Committee Staff to work out a more carefully considered provision in the immediate future. Indeed, it was in effect so stated in the conference report. The promised revision appeared in the Excess Profits Tax Amendments of I94I and was further enlarged and perfected in the I942 Act. This important subject will be discussed below.

It is natural that, as experience has been accumulated and the burden of the excess profits tax has become more severe because of rate increases and other changes, other refinements than those contained in the original Act or specifically indicated for further study have been made. In accordance with the real nature of these provisions, the following discussion will be grouped under three headings: (a) Refinements of income computation, (b) Refinements of credit computation, and (c) Reconstructed base period experience.

\section{(a) Refinements of Income Computation}

(I) Carry-Over and Carry-Back

Of primary importance is the system of carry-overs and carry-backs which has been devised to mitigate the hardships of a strict application of the taxable year concept in the case of a tax such as the excess profits tax. The original Act, as finally approved, contained only a limited unused excess profits credit carry-over, restricted to one year and applicable only to corporations whose normal tax net income did not exceed $\$ 25,000$. At an early stage the Bill had contained a twoyear carry-over applicable to the canning industry alone, but this was eliminated in conference. The limited one-year carry-over above described never in fact became effective, because, before the first year in which any carry-over became available, the 
Excess Profits Tax Amendments of I94I provided a full two-year provision on the order of the net operating loss deduction. A two-year system of carry-backs has been added by the Revenue Act of 1942, that is, an unused excess profits credit in any year may be availed of until exhausted as a further offset to income in the two preceding and two succeeding taxable years in chronological order. The first year to which a carry-back may be taken is r941. This combination of carry-overs and carry-backs should go far to averaging excess profits over a sufficiently long period to prevent the type of hardship which would otherwise result from an uneven profit experience.

\section{(2) Income Related to Other Years}

Any tax in which the annual volume of income and the time of its realization are as important as they are in the excess profits tax presents the problem of the realization in one year of income attributable in whole or in part to one or more other taxable years. Conspicuous among these types of income is income arising from a claim, award, judgment or decree, from a long-term contract, or any other type of income-which was earned or the foundation for which was laid in some taxable year other than that in which it is includible in gross income under the tax laws.

The hardship which might arise in these cases was early realized, and a special provision extending relief was included in the original Act. This relief took the form of permitting a reallocation of the income to the years to which attributable. An alternative tax was then provided for the taxable year, consisting of an amount computed without including in gross income the income attributable to other years, plus the additional tax which would have been payable for the years involved in the reallocation if the income attributable thereto had actually been realized in such years. Subsequent revenue acts have made substantial improvements in the mechanics of this section, but there has been no alteration of its basic policy.

In addition to the types of income already mentioned, the section extended this treatment to income resulting from exploration, discovery, prospecting, research, or development of tangible property, patents, or processes, income includible in one taxable year rather than a different one by reason of a change in accounting period or method of accounting, income resulting to a lessor from the termination of a lease, and income consisting of foreign dividends. No change in these categories has taken place since I940 except for the inclusion by the Excess Profits Tax Amendments of $194 \mathrm{I}$ of a catch-all clause embracing any other types of income after classification pursuant to regulations of the Commissioner. An over-all limitation has been present from the beginning, denying relief unless the income in question is abnormal, either in kind or in amount.

A controversy involving this provision, which should be mentioned in passing, has been whether abnormal income in the taxable year which is attributable to a base period year should have the effect of increasing average base period net income, 
and consequently the average earnings credit. The Finance Committee report indicated that this was to be the case, ${ }^{11}$ but changes in language as the Bill passed through the Conference Committee appeared to the Treasury to prevent it. Consequently, the regulations took the contrary view. This controversy has now been settled by the Revenue Act of 1942 , which makes it plain that Section 721 is to have no effect upon the computation of base period net income. However, a special provision was enacted covering long-term contracts, under which, by permitting taxpayers to elect to redetermine income on a percentage of completion basis for all taxable years, including the base period, the reallocation of income is allowed to increase average base period net income. It will be noted that this privilege is accompanied by the requirement that income of the same nature attributable to years prior to 1936 be eliminated.

\section{(3) Installment Income}

The problems relative to installment income bear many resemblances to those which called forth Section 72x. Yet it was not until the 1942 Act that any provision was made for adjustment in hardship cases of this character. The reason for this delay, as will be seen from the nature of the problem, is probably that restrictions on installment selling and upon the production and sale of civilian goods are a 1942 phenomenon.

The difficulty in these cases is that, though the taxpayer reaches a year when its volume of business has dropped or down payments are required to be larger, with a resulting increased income reflection of current transactions, nevertheless a large volume of past transactions continues to be reflected in income because of collections on prior installment sales. To meet this problem, Section $736(\mathrm{a})$ now grants taxpayers the privilege of recomputing all installment sales on the accrual basis for excess profits tax purposes. All excess profits tax taxable years must be converted to this basis, however, and, furthermore, for the privilege to arise at all, there must be a variance of more than $125 \%$ between the current year and the four preceding years either in the volume of credit extended to purchasers on the installment plan or in the average outstanding installment accounts receivable at the end of each year.

\section{(b) Refinements of Credit Computation}

Much of the development of the Excess Profits Tax Act bearing upon refinements of the credit has already been discussed. Both the growth formula for computing average period net income and the evolution of the deficit year treatment have been fully set forth in the section dealing with the excess profits credit. The only remaining significant development other than Section 722, which will be discussed under (c), is the subject of abnormal deductions in the base period.

In the original Excess Profits Tax Act provision was made for the elimination of abnormal deductions in the base period arising from judgments, awards, decrees, etc. or from development expenses in the case of mines and oil or gas wells. The

${ }^{11}$ Sen. ReP. No. 2114, 76th Cong., 3d Sess. (1940) 16. 
object being to determine an amount of income representing normal earnings, it was felt that equity required that excessive reduction on account of abnormal items be avoided. The field in which this principle was allowed to operate, however, was obviously very narrow. Nor was any exception made for those cases where the same type of abnormality existed in the taxable year.

The Excess Profits Tax Amendments of 194I both expanded and refined the concept materially. More precise abnormality tests were provided and, though the original categories were retained, a third subparagraph was added which brought all deductions, properly classified, within the scope of the adjustment policy. Furthermore, a series of limitations was devised to prevent increase of base period net income except in meritorious cases, considered from the point of view of the excess profits tax taxable year as well as of the base period year itself.

No changes have been made in the treatment of abnormal deductions since the spring of I94r.

\section{(c) Reconstructed Base Period Experience}

The most important of all the sa-called relief sections is Section 722 , which deals with the use of a constructive average base period net income as the foundation for an average earnings credit in abnormality cases.

As has already been mentioned, Section 722 of the original Act, added by the Senate, was only four lines in length and was not inserted as a definitive provision, but as a stop-gap pending further study of the problem. This temporary provision read as follows:

Sec. 722. Adjustment of Abnormalities in Income and Capital by the Commissioner.

For the purposes of this subchapter, the Commissioner shall also have authority to make such adjustments as may be necessary to adjust abnormalities affecting income or capital, and his decision shall be subject to review by the United States Board of Tax Appeals.

The history of general relief, therefore, really in effect begins with the Excess Profits Tax Amendments of r94r, Section 6 of which completely rewrote Section 722, expanding it from four lines to more than two pages in length. The authority to correct abnormalities in invested capital was withdrawn and the section confined to the adjustment of abnormalities in base period net income. Relief was made to depend upon the establishment by the taxpayer that his business as of January $I$, 1940, was different in character from that engaged in during one or more base period years, or that in one or more base period years normal production, output, or operation was interrupted or diminished because of abnormal events. Furthermore, the statute provided that a difference in the character of the business would be considered to exist only if there was a difference in the products or services furnished, in the capacity for production or operation, or in the ratio of non-borrowed capital to total capital, or if the taxpayer was in existence during only part of its base period or if, prior to January $\mathrm{x}, \mathrm{x} 940$, the taxpayer acquired all or part of the 
assets of a competitor, thereby reducing or eliminating competition. Assuming eligibility under the provision, the abnormality or abnormalities in question were to be cured by the use of a constructive average base period net income representing what would have been earned had the abnormality or abnormalities not been present. Relief was to be had solely by way of refund or offsets to proposed deficiencies, until a constructive average base period net income had been established, when the Commissioner could authorize use of the new credit on subsequent returns. In order to limit the number of claims and to insure that some excess profits tax would be paid in any event, the statute provided that relief was not to be available unless it reduced the tax by more than $10 \%$ and that, even where available, the relief should be limited to the amount by which the tentative reduction in tax exceeded xo\% and should not be allowed to bring the tax below $6 \%$ of the taxpayers normal tax net income for the taxable year.

Study of the subject of general relief continued even after the enactment of the I94I provision. For the better part of the year the Bureau of Internal Revenue and the Treasury were engaged in assembling a dossier of hardship cases with a view to further expansion of Section 722. This study culminated in the revisions made by Section 222 of the Revenue Act of I942, which greatly liberalized the section. The amended section may be applied retroactively to I940. Among the more important amendments made was the extension of the section to cover taxpayers not previously entitled to use the average earnings credit-primarily domestic corporations organized after December 3I, x939.

The basic test which the taxpayer must now meet in order to establish a claim for relief under the amended section is that the excess profits tax otherwise computed results in an excessive and discriminatory tax. Citeria for this determination are set forth in the statute. All the tests by which abnormality was established under the former Section 722 are retained, but many new situations have been added. In the case of a taxpayer in existence prior to January 1 , I940, and therefore one entitled to use the average earnings credit, relief is available if (I) base period operations were impeded by an abnormal event such as a strike, fire, or flood; (2) the taxpayer's business was depressed in the base period because of a temporary economic circumstance, unusual in the case of taxpayer or the industry of which it was a member; (3) the base period of the industry of which the taxpayer was a member does not coincide with the general business cycle; (4) the taxpayer commenced business or changed the character of its business during or immediately prior to the base period; or (5) the taxpayer can point to any other factor affecting its business which may reasonably be considered as resulting in an inadequate standard of normal earnings during the base period, provided the application of the section in such case would not be inconsistent with the principles underlying ( $\mathrm{x}$ ), (2), (3) and (4) and with the conditions and limitations enumerated therein.

The category relating to the change in the character of the business includes as illustrations all the instances listed in the prior section plus the additional situation 
of a change in the operation or management of the business. Furthermore, this provision has been liberalized by taking into account increases of capacity completed after December 3I, I939, as the result of a course of action to which the taxpayer was committed prior to January I, r940. Opportunity is also afforded to take account of normal growth, by permitting the taxpayer, in computing its constructive average base period net income, to assume that its business began, or the change occurred, two years earlier than was actually the case, if this produces a higher earning level by the end of the base period.

The right to relief in the case of corporations organized after December 31, 1939, is grounded on the inadequacy of the invested capital credit. Such inadequacies must be based upon one of three factors, viz., (I) taxpayer has intangible assets which make important contributions to income but which are not includible in invested capital; (2) the taxpayer's business is of a class in which capital is not an important income-producing factor; or (3) the taxpayer's invested capital is abnormally low.

The $6 \%$ and $10 \%$ limitations on relief, which ruled out many taxpayers under the former provision, have been eliminated. Recognition is also given to the hardship of applying Section 722 only by way of refund. Taxpayers more than half of whose income would be subject to excess profits tax without regard to Section 722, may claim the benefits of Section 722 upon their returns and defer the payment of $33 \%$ of the reduction in excess profits tax claimed to result from its application. This tax deferment is without a corresponding adjustment in the normal and surtax and therefore amounts to considerably more than $33 \%$ of any net reduction in total tax.

The test of these provisions will come in their administration. The subject is such that precise rules cannot be laid down, but the major matters of determination must be left to sound judgment.

\section{Treatmant of Speciad Types of Corporations}

\section{(a) Mining Companies}

From the earliest excess profits tax days, the contention was forcefully advanced that special treatment should be provided for natural resource industries. Two purposes were alleged: $(x)$ to encourage the production of "strategic" metals, and (2) to afford some relief where the war has not actually produced any greater profit to the mine owner, but merely caused acceleration in the conversion of a wasting asset into current income.

To take care of the first type of situation, the Senate, in 1940 , incorporated a special provision in the Bill exempting from excess profits tax profits attributable to the mining of certain minerals considered to be strategic and in need of an incentive to production, viz., tungsten, quicksilver, manganese, platinum, antimony, chromite, and tin. The exemption did not take the form of an exclusion from income, but merely provided that the tax otherwise computed should be reduced in the same 
proportion as the exempt income bore to the taxpayer's total income. This provision was repealed in I94I on the ground that "these corporations which make money out of the defense program should bear their share of the tax burden,"12 but was restored in 1942 at the request of the War Production Board. 'This restoration was made retroactively applicable to I94I, thus avoiding any gap in the application of the section. Furthermore, four new metals, sheet mica, tantalum, vanadium, and nickel, were added, producing a list of eleven metals to which special treatment is now accorded under Section 73r.

To provide relief for wasting asset industries-the second of the purposes enumerated above-a complicated provision was inserted in the Code by the Revenue Act of 1942, applicable to a long list of natural resource products, not including oil or gas. In general, the new provision excludes from income an amount representing normal profits upon exempt excess output for the taxable year, exempt excess output being a percentage of excess output (that is, the amount above normal), graduated with reference to the estimated number of recoverable units in the property. This method of computation benefits primarily short-lived mines and not those with large reserve deposits. Coal and iron mines are given an alternative method of computing the income to be excluded. In such cases, it is necessary only to multiply the excess output by one-half the net income per unit of production for the taxable year. A like rule is applied to timber, but without the privilege of an option. Provision is also made in Section 735 for exclusion from income of bonus payments made by United States agencies for production in excess of specified quotas.

\section{(b) Personal Service Corporations}

Personal service corporations have from the beginning been given the option of being subject to the excess profits tax or claiming exemption, but if exemption is claimed, the corporation's shareholders are taxed on their pro rata shares of the corporate income for the year, whether distributed or not. The only question of policy has been the definition of the type of corporation to which these provisions shall apply.

The original House Bill defined such a corporation as one in which invested capital is not a material income-producing factor and whose income is primarily attributable to the activities of shareholders who are regularly engaged in the conduct of its affairs and who, in the aggregate, own at least $80 \%$ of its stock. It was also provided that foreign corporations and corporations $50 \%$ or more of whose gross income consisted of gains, profits, or income derived from trading as a principal were excluded. Though attempts were made in the Senate to broaden the classification and the Bill as it went to conference was extremely confusing, the House provision survived, except for a reduction from 80 to 70 in the percentage of stock ownership required of active shareholders. No changes have been made in this provision since r940.

${ }^{12}$ H. R. REP. No. 1040, 77th Cong., Ist Sess. (I94I) 26. 
It is obvious that many corporations find it difficult to comply with the statutory requirements. Either an amount of capital is required to finance operations which makes it impossible to say that capital is not a material income-producing factor, or the business has become so large and requires so many employees that its income cannot be said to be primarily attributable to the activities of shareholders. Many such corporations will find it necessary to look to Section 722 for relief from what would otherwise be an inequitable tax burden.

The 1942 Act provided that the benefits of personal service classification are lost if the corporation is a member of an affiliated group filing a consolidated return. It is believed that this amendment is largely academic, for it is difficult to imagine a corporation that can meet the other tests of Section 725 and still be a member of an affiliated group.

\section{(c) Exempt Corporations}

For various reasons of policy certain corporations are specifically exempted from the excess profits tax. The list contained in the original Act has undergone no change in substance, and consists of the following:

(I) Corporations exempt from income tax under Section ror;

(2) Foreign personal holding companies;

(3) Mutual investment companies;

(4) Diversified investment companies registered under the Investment Company Act of r940;

(5) Personal holding companies;

(6) Non-resident foreign corporations;

(7) Certain domestic corporations with a large portion of their income from foreign sources;

(8) Certain air-mail carriers.

In connection with the amendments of Supplement Q of Chapter I, the 1942 Act combined (3) and (4) above, so that the Act now contains but one investment company exemption, which runs in favor of regulated investment companies as defined in Section $3^{6 \mathrm{I}}$ without regard to (b) (4). More important, however, is the removal of exemption privileges if a consolidated return is filed. This limitation is a consequence of extending consolidated return privileges for purposes of the income tax as well as the excess profits tax and is designed to insure that the affiliated group will be the same for both taxes.

\section{(d) Consolidated Returns}

Brief mention should be made of the privilege of filing consolidated returns, which was revived for purposes of the excess profits tax by the Second Revenue Act of r940. A tax on excess profits, it was felt, might be capricious and unreasonable if applied on a separate corporation basis to a group of taxpayers which together constituted a single integrated economic entity. The r942 Act completed the cycle by reviving consolidated returns for purposes of the income tax as well. 
The rules governing consolidated returns are set forth in the Regulations ${ }^{13}$ rather than the statute. They are exceedingly intricate and involved and require a separate study in themselves. For the purposes of this summary, it is sufficient to refer to the problem which was at the same time the most fundamental and the most diffcult-the determination of consolidated invested capital. The choice lay between the so-called accounting method, which is to measure a subsidiary's capital by its parent's investment, and the so-called legal method, which eliminated the subsidiary's stock from the parent's capital and used the subsidiary's statutory invested capital as the measure. Both methods were adopted, depending on how the subsidiary's stock is held. If such stock has a cost basis in the hands of the parent, the accounting method is used. If the stock has a carry-over basis, the legal method is used. It is interesting to note the statutory sanction which has been given these rules in Supplement $\mathrm{C}$, which deals with reorganization and liquidation transfers.

With the Revenue Act of 1942 the excess profits tax reached maturity. Further refinements in detail may be forthcoming, but evolution of basic concepts has probably ceased. The major problem is now one of administration which, insofar as Section 722 in particular is concerned, may well have an evolution all its own.

${ }^{13}$ U. S. Treas. Reg. I Io. 